\title{
PENGEMBANGAN KREATIVITAS SISWA SEKOLAH DASAR MELALUI PEMBELAJARAN MATEMATIKA OPEN-ENDED
}

\author{
Hendra Erik Rudyanto *
}

\begin{abstract}
Creativity of learners has become more and more important in the era of glabal competition, because the complexity of problems of all aspects in the modern era keeps on increasing all the time. The teaching and learning mathematics at the elementary school has to give the positive contribution so as to encourage the students, creativity as optimally as possible. Open ended technique of teaching and learning mathematics can assumptively give alternatives of the 'true' solutions to students by experiencing investigation against mathematic problems using their deep thnking skill, so that they can construct alternatives of solution creatively.
\end{abstract}

Keywords: Creativity, Open Ended Technique of Teaching and Learning Mathematics

\begin{abstract}
Abstrak
Kreativitas bagi peserta didik merupakan hal yang sangat penting dalam era persaingan global sebab tingkat kompleksitas permasalahan dalam segala aspek kehidupan modern semakin tinggi. Pembelajaran matematika di sekolah dasar harus memberikan kontribusi yang positif dan memberikan ruang yang seluas-luasnya agar siswa mampu dan berkembang kreatifitasnya. Pembelajaran matematika open-ended dengan banyak alternatif solusi menuju jawaban benar untuk memberikan pengalaman siswa dalam menemukan sesuatu yang baru akan memberikan siswa kesempatan untuk melakukan investigasi masalah matematika secara mendalam, sehingga dapat mengkonstruksi segala kemungkinan pemecahannya secara kreatif.
\end{abstract}

Kata Kunci: Kreativitas, Pembelajaran Matematika Open-ended

\section{A. Pendahuluan}

Kompetensi berpikir kreatif bagi peserta didik merupakan hal yang sangat penting dalam era persaingan global sebab tingkat kompleksitas permasalahan dalam segala aspek kehidupan modern semakin tinggi. Mengingat dunia semakin berkembang dari waktu ke waktu, dan hanya generasi-generasi yang memiliki kemampuan kreatif yang dapat meraih kesuksesan. Undang-undang Nomor 20 Tahun 2003 tentang Sistem Pendidikan Nasional menyatakan pendidikan nasional bertujuan untuk berkembangnya potensi peserta didik agar menjadi manusia yang beriman dan bertakwa kepada Tuhan Yang Maha Esa, berakhlak mulia, sehat,

* Hendra Erik Rudyanto adalah Dosen Prodi PGSD FIP IKIP PGRI MADIUN 
berilmu, cakap, kreatif, mandiri, dan menjadi warga negara yang demokratis serta bertanggung jawab. Berdasarkan tujuan pendidikan nasional tersebut, jelas bahwa pendidikan di setiap jenjang, harus diselenggarakan secara sistematis guna mencapai tujuan tersebut, salah satunya yaitu agar manusia memiliki kreatifitas.

Taksonomi Bloom ranah kognitif yang telah direvisi Anderson dan Krathwohl (2001:66-88) yakni: mengingat (remember), memahami/mengerti (understand), menerapkan (apply), menganalisis (analyze), mengevaluasi (evaluate), dan menciptakan (create). Dari kemampuan dalam taksonomi Bloom, yang paling tinggi adalah kemampuan mencipta (create). Oleh karena dibutuhkan kompetensi kreatif. Jadi berfikir kreatif tergolong kompetensi tingkat tinggi (high order competencies). Suherman (2003) menyatakan bahwa matematika dapat ditinjau dari segala sudut, dan matematika itu sendiri bisa memasuki seluruh segi kehidupan manusia, dari yang paling sederhana sampai kepada yang kompleks. Oleh karena itu matematika perlu diberikan kepada siswa untuk membekali siswa dengan kemampuan berpikir logis, analitis, sistematis, kritis, dan kreatif (Depdiknas, 2006).

Untuk itu guru harus menciptakan pembelajaran yang mengarahkan siswa untuk dapat mengembangkan kemampuan-kemampuan tersebut. Tujuan yang disebutkan menjadikan pentingnya kreatifitas bagi siswa. Berfikir kreatif tergolong kompetensi tingkat tinggi (high order competencies) dan dapat dipandang sebagai kelanjutan dari kompetensi dasar (biasa disebut dengan basic skills dalam pembelajaran matematika). Hal ini sesuai dengan pendapat Ervync (1991) yang menyatakan bahwa kreatifitas memainkan peran yang penting dalam siklus berfikir matematis tingkat lanjut. Menurut Career Center Maine Departmen of Labor USA, kemampuan berfikir kreatif memang penting karena kemampuan ini merupakan salah satu kemampuan yang dikehendaki dunia kerja (Mahmudi, 2010). Andangsari (2007) berpendapat bahwa kemampuan berpikir kreatif biasa terjadi karena seseorang mencoba sesuatu dengan sengaja. Berawal kesengajaan seseorang mampu mengerjakan tugas-tugasnya dan akhirnya terbiasa. Kemampuan berpikir kreatif dapat muncul karena seseorang terbiasa berkreasi.

Dengan demikian, pembelajaran matematika, kini dan di masa datang, tidak boleh berhenti hanya pada pencapaian basic skills, tetapi sebaliknya harus dirancang untuk mencapai kompetensi matematis tingkat tinggi (high order competencies). Perspektif baru ini merupakan tantangan yang harus dijadikan pegangan dalam pembelajaran matematika. Model pembelajaran harus mampu memberikan ruang seluas-luasnya bagi peserta didik dalam membangun pengetahuan dan pengalaman mulai dari basic skills sampai tingkat tinggi. Peserta didik hendaknya diarahkan untuk mencapai kompetensi tingkat tinggi melalui aktivitas-aktivitas pembelajaran dalam memecahkan masalah matematika terbuka. Pemecahan masalah matematika open-ended akan memberikan siswa kesempatan untuk melakukan investigasi masalah matematika secara mendalam, sehingga dapat mengkonstruksi segala kemungkinan pemecahannya secara kreatif. Menurut Getzel \& Jackson, kreatifitas dalam bidang matematika dapat diukur dengan pertanyaan open ended yang menyediakan lebih dari satu jawaban (Silver, 1997). Sehingga pendekatan masalah matematika open-ended merupakan salah satu pembelajaran yang melibatkan para siswa yang dapat membangun ketrampilan berfikir kreatif dan membuat siswa aktif dalam aktivitas belajar. 


\section{B. Pembahasan}

\section{Berpikir Kreatif}

Dengan kreatifitas akan menghasilkan ide-ide baru dalam mengatasi suatu masalah masalah. Solso (2008: 444) mendefinisikan kreativitas adalah suatu aktifitas kognitif yang menghasilkan pandangan yang baru mengenai suatu bentuk permasalahan dan tidak dibatasi pada hasil yang pragmatis (selalu dipandang menurut kegunaanya). Menurut Santrock (2010: 366) kreatifitas ialah kemampuan berpikir tentang sesuatu dengan cara baru dan tidak biasa dan menghasilkan solusi yang unik atas suatu masalah. Sedangkan Munandar (2002:25-29) mendefinisikan pengertian kreativitas dengan menggunakan pendekatan pribadi, proses, produk, dan pendorong.

Definisi pribadi yang menyatakan bahwa kreativitas merupakan perilaku seseorang yang memiliki kepribadian mengagumkan dalam menghadapi dan hidup bermasyarakat dengan cara yang unik. Seseorang yang memiliki kemampuan berpikir kreatif akan dapat memiliki karakteristik atau ciri khas yang berbeda walaupun berada dalam lingkungan yang sama dengan orang lain. Definisi proses, menjelaskan tentang proses yang dilakukan oleh seseorang dengan kemampuan berpikir kreatif antara lain mengerti adanya permasalahan, kesulitan, perbedaan informasi terhadap suatu hal, bagian-bagian yang hilang dalam informasi, atau beberapa hal yang menjadi pertanyaan sehingga mampu membuat praduga atau hipotesis berkaitan dengan kekurangan yang baru ditemukan. Praduga yang telah dibuat selanjutnya dievaluasi dan hasil yang telah diperoleh dikomunikasikan. Definisi produk, di mana produk yang dihasilkan oleh orang yang memiliki kemampuan berpikir kreatif akan menghasilkan produk yang lebih menekankan pada unsur-unsur orisinalitas, kebaruan, dan kebermaknaan. Rogers mengemukakan kriteria produk yang harus dihasilkan oleh orang-orang yang dapat berpikir kreatif antara lain nyata (observable), baru, dan merupakan hasil dari kualitas unik individu dalam interaksi dengan lingkungannya (Munandar, 2002: 28). Definisi pendorong, yang menyatakan bahwa kemampuan berpikir kreatif pada seseorang akan dapat muncul dengan baik jika orang tersebut memiliki motivasi intrinsik yang baik dan berada pada lingkungan yang mendorong kreativitas orang tersebut secara positif.

Anwar (2012) berpendapat berpikir kreatif adalah cara baru dalam melihat dan mengerjakan sesuatu yang memuat 4 aspek yaitu: fluency (kefasihan), flexybility (keluwesan), originality (keaslian), dan elaboration (keterincian).

a. Aspek fluency (kefasihan)

Aspek kefasihan terkait dengan cara siswa membangun ide. Kefasihan dalam berfikir kreatif mengacu pada beragamnya jawaban benar yang diberikan kepada siswa. Dalam aspek ini, jawaban yang berbeda belum tentu dianggap beragam.

b. Aspek flexybility (keluwesan)

Aspek keluwesan dalam berfikir kreatif mengarah pada kemampuan siswa untuk memecahkan masalah dengan beragam cara penyelesaian yang berbeda. Penggunaan cara yang berbeda ini diawali dengan memandang permasalahan yang diberikan dari sudut pandang yang berbeda.

c. Aspek originality (keaslian) 
Keaslian jawaban atau cara penyelesaian terkait dengan berapa siswa yang memberikan jawaban atau cara penyelesaian tersebut. Semakin jarang siswa memberikan suatu jawaban yang sama atau cara penyelesaian yang sama, semakin tinggi tingkat keaslian jawaban tersebut. Namun aspek ini juga tetap harus mempertimbangkan kesesuaian dan kemanfaatan jawaban.

d. Aspek elaboration (keterincian)

Aspek keterincian terkait dengan kemampuan siswa untuk menjelaskan secara runtut, rinci, dan saling terkait antara satu langkah dengan langkah yang lain. Penggunaan konsep, istilah, dan notasi yang sesuai juga dipertimbangkan dalam aspek ini.

\section{Pembelajaran Open-Ended}

\section{a. Pengertian Pembelajaran Open-Ended}

Shimada mendefinisikan pembelajaran dengan pendekatan open-ended dimulai dengan mempresentasikan permasalahan open ended terlebih dahulu kemudian pembelajaran diproses dengan menggunakan banyak jawaban benar untuk memberkan siswa pengalaman dalam menemukan sesuatu yang baru (Takashi, 2005). Masalah yang disusun sedemikian rupa hingga memiliki jawaban yang benar (banyak penyelesaian) disebut masalah open-ended atau soal-soal terbuka. Terdapat definisi dari para ahli tentang open-ended. Menurut Suherman dkk. (2003) problem yang diformulasikan memiliki multi jawaban yang benar disebut problem tak lengkap atau disebut juga open-ended problem (soal terbuka). Shimada (1997:1) mengemukakan:

Open-ended approach, an incomplete problem is presented first. The lesson than proceeds by using many correct answers to the given problem to provide experience in finding something new in the process. This can be done through combining students own knowledge, skills, or ways of thinking that have previously been learned.

Pendekatan terbuka adalah suatu permasalahan yang tidak sempurna yang dikenalkan terlebih dahulu. Pelajaran mengutamakan proses dengan menggunakan jawaban yang benar, atas masalah yang diberikan untuk memberikan pengalaman di dalam menemukan sesuatu yang baru dalam proses tersebut. Proses ini bisa dilakukan melalui kombinasi pengetahuan yang dimiliki siswa, ketrampilan atau cara berfikir yang sudah dipelajari oleh siswa sebelumnya. Berdasarkan kedua pendapat di atas dapat disimpulkan bahwa pembelajaran dengan pendekatan openended adalah suatu permasalahan terbuka yang diberikan kepada siswa dengan pengetahuan, cara, dan metode yang berbeda dalam menjawab permasalahan yang diberikan. Bukan berorientasi pada jawaban (hasil akhir) namun dalam proses yang diharapkan pada merangsang kemampuan intelektual dan pengalaman siswa dalam menemukan sesuatu yang baru. Menurut Coney (2002), pertanyaan open ended memiliki ciri-ciri sebagai berikut: (1) melibatkan matematika yang penting; (2) menghasilkan jawaban yang beragam; (3) membutuhkan komunikasi; dan (4) dinyatakan dengan jelas.

\section{b. Tujuan Pembelajaran Berbasis Open-Ended}

Menurut Nohda tujuan pembelajaran berbasis open-ended ialah membantu mengembangkan kegiatan kreatif dan pola pikir matematika siswa melalui 
problem possing secara simultan (Suherman, 2003: 124). Dengan kata lain, kegiatan kreatif dalam pola pikir matematika siswa harus dikembangkan semaksimal mungkin sesuai dengan kemampuan yang dimilki setiap siswa. Pendekatan open-ended memberikan kesempatan kepada siswa untuk menginvestasikan berbagai strategi dan cara yang diyakininya sesuai dengan kemampuan yang dimiliki untuk mengelaborasikan permasalahan. Tujuannya tiada lain adalah agar kemampuan berfikir matematika siswa dapat berkembang secara maksimal dan pada saat yang sama kegiatan-kegiatan kreatif dari setiap siswa terkomunikasikan melalui proses pembelajaran. Inilah yang menjadi pokok pikiran pembelajaran dengan pendekatan open-ended, yaitu pembelajaran yang membangun kegiatan interaktif antara matematika dan siswa sehingga mendorong siswa untuk menjawab permasalahan melalui berbagai strategi.

Pendekatan open-ended adalah suatu pendekatan pemecahan masalah yang diyakini dapat mendorong kreativitas dan inovasi berpikir matematika siswa secara lebih bervariasi. Pendekatan ini juga dapat mendorong siswa untuk berpikir lebih kritis, tebuka, mampu bekerja sama, dan berkompeten dalam pemecahan masalah dan berkomunikasi secara logis dan argumentatif. Selain itu, pendekatan pemecahan masalah open-ended juga memungkinkan meningkatnya penalaran dan komunikasi matematika Hal ini disebabkan oleh pendekatan pemecahan masalah open-ended dilakukan dengan penyajian masalah yang memiliki lebih dari satu jawaban benar atau banyak cara mendapatkan jawaban benar tersebut. Dalam memberikan alternatif jawaban, siswa secara bebas menggunakan segala kemampuan, ide-ide, dan skill matematikanya.

Dengan dimungkinkannya memberikan berbagai jawaban, siswa menjadi terlatih untuk bernalar dan mengkomunikasikan ide-idenya dalam memberikan klarifikasi dan alasan-alasan terkait dengan jawabannya. Misalnya siswa mengintegrasikan apa yang telah ia pelajari mengenai macam-macam bangun datar dan berbagai bentuk garis, misalnya memilih bentuk bangun datar yang mana yang mempunyai garis yang lurus dan mana bentuk bangun datar yang memiliki garis yang merupakan lungkungan atau seperti kurva. Soal terbuka seperti ini disajikan dengan maksud guru dapat mengemukakan permasalahan dalam format sederhana sehingga dapat direspon siswa dengan cepat.

\section{c. Aspek-Aspek Pendekatan Open-Ended}

Kegiatan matematika dan kegiatan siswa disebut terbuka jika memenuhi ketiga aspek, yaitu: (1) kegiatan siswa harus terbuka. Yang dimaksud kegiatan siswa harus terbuka adalah kegiatan pembelajaran harus mengakomodasi kesempatan siswa untuk melakukan segala sesuatu secara bebas sesuai kehendak mereka; (2) kegiatan matematika merupakan ragam berfikir. Kegiatan matematika adalah kegiatan yang didalamnya terjadi proses pengabstraksian dari pengalaman nyata dalam kehidupan sehari-hari ke dalam dunia matematika atau sebaliknya; dan (3) kegiatan siswa dan kegiatan matematika merupakan suatu kesatuan.

Guru galam pembelajaran matematika, diharapkan dapat mengangkat pemahaman dalam berfikir matematika sesuai dengan kemampuan individu. Meskipun pada umumnya guru akan mempersiapkan dan melaksanakan pembelajaran sesuai dengan pengalaman dan pertimbangan masing-masing. Guru bisa membelajarkan siswa melalui kegiatan-kegiatan matematika tingkat tinggi yang sistematis atau melalui kegiatan-kegiatan matematika yang mendasar untuk 
melayani siswa yang kemampuannya rendah. Pendekatan uniteral semacam ini dapat dikatakan terbuka terhadap kebutuhan siswa ataupun terbuka terhadap ideide matematika.

\section{Pengembangan Kreatifitas Siswa Sekolah Dasar melalui Pembelajaran Matematika Open-Ended}

Setiap masalah dan tantangan yang dianggap sulit untuk dipecahkan mungkin masih ada solusinya, namun belum terpikirkan oleh manusia. Bagaimana agar manusia bisa menemukan solusi yang kelihatannya tidak ada tersebut? Jawabannya ialah dengan mencarinya. Bagaimana manusia bisa menemukannya jika tidak mencari. Proses pencarian inilah yang disebut dengan proses berpikir kreatif. Berfikir merupakan kemampuan khusus yang dimiliki manusia dan tidak dimiliki mahluk lainnya. Dalam kehidupan sehari-hari, berfikir seakan merupakan sebuah proses yang alami tanpa direncanakan. Namun sesungguhnya proses berfikir yang dilakukan sehari-hari merupakan sebuah proses yang rumit dan melibatkan banyak komponen, demikian jika manusia melihatnya dalam perspektif kreatifitas. Sehingga untuk menentukan kreatifitas berfikir seseorang diperlukan beberapa komponen variabel. Penentuan kriteria kreativitas menyangkut tiga dimensi yaitu dimensi proses, orang atau pribadi, dan produk kreatif. Dengan menggunakan proses kreatif sebagai kriteria kreativitas, maka segala produk yang dihasilkan dari proses itu dianggap sebagai produk kreatif, dan orangnya disebut sebagai orang kreatif.

Anak sedini mungkin harus dikenalkan dengan hal-hal yang dapat mengembangkan kreatifitasnya, dan jenjang Sekolah Dasar adalah tahap yang paling tepat untuk mengenalkannya. Pembelajaran matematika harus memberikan kontribusi yang positif agar siswa mampu dan berkembang kreatifitasnya, sehingga tujuan pembelajaran matematika dapat tercapai. Basic skills dalam pembelajaran matematika biasanya dibentuk melalui aktivitas yang bersifat konvergen. Aktivitas ini umumnya cenderung berupa latihan-latihan matematika yang bersifat algoritmik, mekanistik, dan rutin. Namun, kompetensi berpikir kreatif bersifat divergen dan menuntut aktivitas investigasi masalah matematika dari berbagai perspektif. Melalui investigasi, siswa dapat mengoptimalkan pengetahuannya untuk menyelesaikan berbagai permasalahan.

Tetapi dalam kenyataannya, pembelajaran matematika yang dilaksanakan guru, terutama pada siswa Sekolah Dasar, masih didominasi oleh aktivitas latihanlatihan untuk pencapaian mathematical basics skils semata. Guru kurang memperhatikan pada aktivitas belajar siswa yang mengarah proses berpikir divergen karena guru tidak sempat mempertimbangkan untuk menganalisis proses berfikir kreatif siswa, sehingga guru hanya memberikan soal-soal rutin pada saat pembelajaran maupun evaluasinya. Hal itulah sebagai salah satu penyebab kurangnya minat siswa dalam belajar matematika siswa. Peserta didik hendaknya diarahkan untuk mencapai kompetensi tingkat tinggi melalui aktivitas-aktivitas pembelajaran dalam memecahkan masalah matematika open-ended. Berikut beberapa contoh soal open-ended yang dikembangkan Gembong (2013) berdasarkan penelitian yang dapat membangun kemampuan berpikir kreatif: (1) berapa ekor ayam yang diperlukan agar beratnya sama dengan 1 ekor kelinci? (2) jarak kota A dan kota B adalah $100 \mathrm{~km}$. Jika Amir naik mobil dari kota A pukul 10.00, pukul berapa Amir tiba di kota B? 
Pemecahan masalah matematika open-ended akan memberikan siswa kesempatan untuk melakukan investigasi masalah matematika secara mendalam, sehingga dapat mengkonstruksi segala kemungkinan pemecahannya secara kritis dan kreatif. Sehingga, pembelajaran matematika open-ended adalah salah satu pendekatan pembelajaran yang melibatkan para siswa untuk menumbuhkan ketrampilan berfikir kreatif dan membuat siswa aktif dalam aktivitas belajar.

\section{Penutup}

Pembelajaran matematika, kini dan di masa datang, tidak boleh berhenti hanya pada pencapaian basic skills, tetapi sebaliknya harus dirancang untuk mencapai kompetensi matematis tingkat tinggi (high order competencies) yaitu salah satunya dengan mengembangkan kemampuan kreatif siswa. Perspektif baru ini merupakan tantangan yang harus dijadikan pegangan dalam pembelajaran matematika. Model pembelajaran harus mampu memberikan ruang seluas-luasnya bagi peserta didik dalam membangun pengetahuan dan pengalaman mulai dari basic skills sampai tingkat tinggi agar kreatifitas siswa dapat berkembang, hal ini sangat relevan mengingat masalah dunia nyata umumnya tidak sederhana dan konvergen, tetapi kompleks dan divergen, bahkan tak terduga. 


\section{DAFTAR RUJUKAN}

Anderson, L.W., dan Krathwohl, D. R. 2001. A Taxonomy for Learning, Teaching, and Assesing: A Revision of Bloom's Taxonomy of Educatioanl Objectives. New York: Addison Wesley Longman, Inc.

Anwar, N. M. 2012. Relationship of Creative Thinking with Academc Achievements of secondary School Students. International Interdiciplinary Journal of Education, 1(3): 12-24.

Cooney, T. J. 2002. Open Ended Assesment in Math, (Online). (http:heinemann.com/math/about.ctf, diakses 9 Juni 2013).

Depdiknas. 2006. Peraturan Menteri Pendidikan Nasional Republik Indonesia Nomor 22 Tahun 2006 tentang Standar Isi untuk Satuan Pendidikan Dasar dan Menengah, (Online), (http://www.indonesia.go.id, diakses 3 November 2013).

Envync, G. 1991. Mathematical Creativity. Dalam Tall, D (Eds), Advanced Mathematical Learning. London: Kluwer Academic Publisher.

Gembong, S. 2013. Pengembangan Soal Open-Ended untuk Membangun Kemampuan Berpikir Kreatif dalam Memecahkan Masalah Matematika pada Siswa Sekolah Dasar. Laporan Penelitian tidak diterbitkan. Madiun: LPPM IKIP PGRI MADIUN.

Mahmudi, A. 2010. Mengukur Kemampuan Berpikir Kreatif Matematis. Makalah disajikan pada Konferensi Nasional Matematika XV UNIMA.

Munandar, S. C. U. 2002. Kreativitas dan Keberbakatan Strategi Mewujudkan Potensi Kreatif dan Bakat. Jakarta: PT Gramedia Pustaka Utama.

Munandar, U. 1999. Pengembangan Kreatifitas Anak Berbakat. Jakarta: PT Rineka Cipta.

Santrock, J. W. 2010. Psikologi Pendidikan. Jakarta: Kencana Prenada Media Group.

Silver, E. A. 1997. Fostering Creativity Through Instruction Rich in Mathematical Problem Solving and Problem Posing. Zentralblatt für Didaktik der Mathematik (ZDM) - The International Journal on Mathematics Education. (Online). (http://www.emis.de/journals/ZDM/ zdm973a3.pdf. ISSN 1615-679X, diakses 5 Juni 2013).

Solso, R. L. 2008. Psikologi Kognitif. Jakarta: Erlangga.

Suherman, E. 2003. Strategi Pembelajaran Matematika Kontemporer. Bandung: JICA. 
Takahashi, A. 2005. An Overview What is an Open Ended Approach. Makalah disajikan pada The Park City Mathematics Institute Secondary School Teacher Program.

Undang-Undang Republik Indonesia Nomor 20 Tahun 2003 tentang Sistem Pendidikan Nasional. 2004. Bandung: Citra Umbara. 